\title{
Kelimpahan dan Keanekaragaman Predator Laba-Laba pada Ekosistem Sawah Padi Hitam (Oryza sativa L.) Berpupuk Organik
}

\author{
Vira Kusuma Dewi ${ }^{1}$, Octaviani ${ }^{2}$, Santika Sari ${ }^{3}$, Sri Hartati ${ }^{1}$, Toto Sunarto ${ }^{1}$, Lilian Rizkie ${ }^{1}$, dan \\ Yongki Umam Sandi ${ }^{2}$ \\ ${ }^{1}$ Departemen Hama dan Penyakit Tumbuhan, Fakultas Pertanian, Universitas Padjadjaran \\ ${ }^{2}$ Program Studi Agroteknologi, Fakultas Pertanian, Universitas Padjadjaran \\ ${ }^{3}$ Departemen Budidaya Pertanian, Fakultas Pertanian Universitas Padjadjaran \\ J1. Raya Bandung-Sumedang KM-21, Jatinangor 45363 \\ *Alamat korespondensi: vira.kusuma.dewi@unpad.ac.id
}

\begin{abstract}
Abundance and diversity of predatory spider in black paddy fields ecosystem using organic fertilizers
\end{abstract}

Spiders are the main predators in rice ecosystem. Application of fertilizer such as neem cake and siam weed compost is not expected to have any negative effect on spiders in the paddy field. This study was conducted to analyze the effect of neem cake and siam weed compost on abundance and species diversity of predatory spiders of rice pests on black rice ecosystem. The experiment was carried out in paddy field at Cinenggang, Cileles Village, Jatinangor from May to November 2018. The experimental method was used a randomized Complete Block Design and followed by five treatments (neem cake, siam weed compost, cow manure, synthetic fertilizer and control) with six replications. The result showed that the total number of spider's family were caught at study site as mush as eight families that are Tetragnathidae, Pholcidae, Linyphiidae, Lycosidae, Theridiidae, Oxyopidae, Clubionidae, Araneidae. The family Tetragnathidae was the most abundant, followed by Pholcidae and Linyphiidae. Furhermore, the total abundance, Shannon, Evenness, the dominance, and the similarity indices of spiders were tended to be higher in neem cake and siam weed compost treatment if compared with synthetic fertilizer and control treatment.

Keywords: Araneae, Cow manure, Neem cake, Siam weed, Organic

\begin{abstract}
ABSTRAK
Laba-laba merupakan salah satu predator penting dalam mengatur populasi serangga hama di ekosistem padi. Aplikasi pupuk ampas bungkil mimba dan kompos gulma siam diharapkan meningkatkan keberadaan laba-laba. Tujuan penelitian adalah untuk menganalisis kelimpahan dan keanekaragaman laba-laba pada ekosistem sawah padi hitam berpupuk organik asal ampas bungkil mimba dan gulma siam. Percobaan dilaksanakan di Cinenggang, Desa Cileles, Kecamatan Jatinangor, Kabupaten Sumedang, sejak bulan Mei - November 2018. Penelitian dilakukan dengan metode Rancangan Acak Kelompok (RAK) dengan lima perlakuan yaitu kontrol, NPK, pupuk ampas mimba, kompos gulma siam, dan pupuk kandang sapi dengan dilakukan enam ulangan. Hasil penelitian diperoleh delapan famili laba-laba yaitu Tetragnathidae, Pholcidae, Linyphiidae, Lycosidae, Theridiidae, Oxyopidae, Clubionidae dan Araneidae. Famili yang paling dominan pada semua perlakuan adalah Tetragnathidae, dan selanjutnya diikuti oleh Famili Pholcidae dan Linyphiidae. Jumlah total laba-laba, indeks keragaman, kelimpahan, kekayaan dan kemerataan spesies diketahui cenderung lebih tinggi pada perlakuan pupuk ampas bungkil mimba dan kompos gulma siam daripada perlakuan NPK dan kontrol.
\end{abstract}

Kata Kunci: Ampas bungkil mimba, Araneae, Gulma siam, Pupuk kotoran sapi, Organik 


\section{PENDAHULUAN}

Budidaya padi hitam secara organik adalah budidaya padi tanpa menggunakan bahan kimia sintetik baik pestisida maupun pupuk. Padi hitam (Oryza sativa L.) merupakan varietas yang semakin banyak dikonsumsi sebagai makanan fungsional di kalangan masyarakat (Kristamtini \& Purwaningsih, 2009). Pada umumnya, padi hitam hanya tumbuh dan dibudidayakan di daerah-daerah tertentu. Menurut Wahdah \& Langai (2009), padi hitam memiliki peluang yang baik dan sangat menguntungkan untuk dikembangkan. Oleh karena itu, perlu dilakukan upaya untuk peningkatan produkivitas padi hitam.

Peningkatan produksi tanaman padi sangat berkaitan erat dengan keberadaan arthropoda pada pertanaman. Arthropoda berdasarkan keanekaragaman fungsinya di ekosistem sawah terbagi menjadi herbivor, musuh alami, dekomposer, polinator dan organisme lain yang merupakan komponen penting lingkungan (Altieri \& Nicholls, 1999). Keanekaragaman arthropoda menentukan kestabilan ekosistem pada persawahan. Ekosistem yang stabil menggambarkan keseimbangan populasi antara arthropoda yang berperan sebagai herbivor, musuh alami dan organisme lainnya sehingga kerusakan tanaman berkurang (Siswanto \& Wiratmo, 2001). Pada ekosistem sawah, laba-laba merupakan musuh alami yang berperan penting dalam menekan populasi hama, seperti wereng coklat dan penggerek batang (Settle et al. 1996; Hendrival dkk., 2011).

Laba-laba banyak ditemukan pada pertanaman padi dan memangsa berbagai spesies hama (Sosromarsono \& Untung, 2000). Jumlah spesies laba-laba yang telah teridentifikasi sampai saat ini sekitar 43.678 spesies, yang terbagi dalam 111 famili dan 3600 genus (Anjali \& Prakash, 2012). Berdasarkan peranannya sebagai predator hama, laba-laba mempunyai arti penting dalam menjaga kestabilan rantai makanan (Memah et al., 2014). Wilson et al. (2008) menegaskan bahwa kelimpahan, keanekaragaman dan komposisi organisme bervariasi tergantung pada sistem budidaya, pola tanam dan lingkungan.

Menurut Hadi dan Aminah (2012), sawah organik memiliki kekayaan morphospesies dan keragaman arthropoda yang tinggi bila dibandingkan dengan sawah konvensional. Berdasarkan penelitian Anggraini (2014), diketahui bahwa sawah organik memiliki tingkat kepadatan laba-laba pembuat jaring dan persentase hunian laba-laba lebih tinggi dibandingkan dengan sawah konvensional yaitu 44 spesies dari 13 famili. Tingginya populasi musuh alami pada pertanaman organik dibandingkan dengan sistem konvensional tidak lain dipengaruhi oleh dampak input teknologi yang digunakan (Makarim \& Las, 2005). Menurut Widiarta dkk. (2001) pertanaman yang menggunakan sistem budidaya organik mampu menekan populasi serangga hama dan mempertahankan keberadaan musuh alami di lapangan. Adapun salah satu upaya mendukung pertanian organik adalah menggunakan bahanbahan alami sebagai pengganti pupuk sintetik.

Terkait peningkatan produktivitas padi, manfaat utama pupuk organik adalah memperbaiki sifat kimia, fisik, dan biologi tanah, serta meningkatkan keanekaragaman laba-laba pada pertanaman (Settle et al., 1996). Salah satu cara yang dilakukan untuk mempertahankan lahan pertanian agar tetap produktif dan berkelanjutan adalah dengan mengembalikan bahan organik ke dalam tanah (Marsono \& Sigit, 2001). Adapun bahanbahan organik yang dapat dimanfaatkan sebagai kompos adalah gulma siam (Chromolaena odorata L) dan ampas bungkil mimba (Azadirachta indica A).

Gulma siam mengandung bahan aktif seperti asam palmitat, 12 fenolik, sesquiterpen, aldehida, dan furfuril alkohol, metoksi flavon, dan minyak atsiri (Ulpa, 2008). Menurut Radix dan Aeny (2011) gulma siam tersebar merata di berbagai lokasi dan ketersediaannya berlimpah. Gulma siam merupakan sumber bahan organik potensial, bahkan diketahui kandungan $\mathrm{N}, \mathrm{K}$, dan Ca pada bahan organik ini lebih tinggi daripada pupuk kandang sapi (Suntoro, 2001; Dewi dkk., 2019). Menurut Amengor dan Tetteh (2008), aplikasi C. odorata sebagai bahan organik dapat digunakan sebagai pupuk hijau, mulsa, atau kompos.

Adapun pemanfaatan ampas bungkil mimba memiliki dua peran yaitu sebagai pupuk dan pestisida nabati. Ampas bungkil mimba mengandung beberapa komponen aktif pestisida antara lain azadirakhtin, salanin, azadiradion, salannol, salanolacetat, 3-deasetil salanin, 14-epoksiazadiradion, gedunin, nimbin, dan deasetil nimbin. Pada beberapa komponen tersebut ada empat senyawa yang diketahui sebagai pestisida, yaitu azadirakhtin, salanin, nimbin, dan meliantriol (Schmutterer, 1990). Keempat senyawa ini diketahui mampu memengaruhi prilaku makan, pertumbuhan dan reproduksi serangga. Lebih lanjut, dilaporkan bahwa pemberian ampas bungkil mimba dapat memberikan hasil produksi yang tinggi bila 
dibandingkan dengan penggunaan pupuk NPK pada pertanaman lada (Rivaie, 2009). Berdasarkan beberapa penelitian yang dilakukan maka ampas bungkil mimba ini berpotensi sebagai pupuk organik sekaligus pestisida nabati. Oleh karena itu, penelitian ini bertujuan untuk mengetahui pengaruh pupuk organik gulma siam dan ampas bungkil mimba terhadap kelimpahan dan keanekaragaman laba-laba pada ekosistem sawah padi hitam.

\section{BAHAN DAN METODE}

Penelitian ini dilaksanakan pada bulan Mei hingga November 2018 yang berlokasi di lahan sawah Kampung Cinenggang, Desa Cileles dan Laboratorium Hama Tanaman, Fakultas Pertanian, Universitas Padjadjaran. Penelitian menggunakan metode eksperimen dengan Rancangan Acak Kelompok (RAK). Jumlah perlakuan pada penelitian terdiri atas 5 taraf perlakuan dengan 6 kali ulangan. Adapun perlakuan terdiri atas kontrol (tanpa perlakuan), pupuk ampas bungkil mimba (12 $\mathrm{kg} / \mathrm{plot}$ ), kompos gulma siam (12 kg/plot), pupuk kohe sapi (12 kg/plot) dan NPK Mutiara (180 g/plot).

\section{Pembuatan Kompos Gulma Siam}

Tahap awal dilakukan pengumpulan daun gulma siam. Selanjutnya, daun gulma siam dicacah hingga halus kemudian ditimbang, dihamparkan dan ditambahkan air hingga basah serta ditaburi stardeck (MOL) sebanyak 6,25 g/25 kg gulma siam dan dicampur merata. Setelah tercampur rata, gulma siam ditimbun di dalam kotak kayu berukuran 2 x 1 x $1 \mathrm{~m}$. Monitoring dilakukan rutin setiap satu minggu sekali untuk pembalikan kompos dan penambahan air agar kelembaban kompos tetap terjaga. Selain itu, penambahan gula pasir dan EM4 sesuai anjuran dosis dilakukan untuk memberikan nutrisi pada dekomposer. Proses pengomposan dilakukan \pm 4 minggu dan apabila timbunan gulma siam telah berubah warna menjadi kehitaman dan teksturnya seperti remahan tanah maka dapat dikatakan kompos telah matang.

\section{Persiapan Pupuk Ampas Bungkil Mimba}

Pupuk ampas bungkil mimba diperoleh dari Puspromit Departemen Hama dan Penyakit Tanaman, Fakultas Pertanian, Universitas Padjadjaran. Tahap awal dilakukan pengumpulan bungkil mimba yang sudah berupa ampas dari pengepresan. Selanjutnya ampas bungkil mimba ditimbang, dihamparkan dan dikeringkan.
Pengeringan dilakukan dengan bantuan angin agar ampas bungkil mimba tidak terserang jamur.

\section{Persiapan Lahan Penanaman Padi}

Langkah awal pada tahap persiapan lahan dilakukan pengolahan tanah. Setelah tanah dibajak kemudian dibiarkan selama satu minggu dalam keadaan tergenang air. Penggenangan air ini dilakukan agar proses pelunakan tanah berlangsung sempurna. Satu minggu kemudian tanah dapat diolah kembali agar bongkahan tanah menjadi makin kecil. Pengolahan kedua dilakukan dengan pencangkulan. Setelah lahan benar-benar dalam kondisi siap tanam, maka pada bagian tengah dibuatkan alur memanjang sepanjang lahan dengan lebar sekitar $50 \mathrm{~cm}$ sebagai saluran keluar masuknya air. Setelah pembuatan plot selesai, penggemburan lahan dilakukan bersamaan dengan penambahan pupuk gulma siam, ampas bungkil mimba dan kotoran sapi sesuai petak perlakuan yang telah ditentukan. Selanjutnya, pemupukan NPK dilakukan 1 minggu setelah tanam (mst). Pada penelitian ini telah dipersiapkan 30 plot yang masing-masing plot berukuran $3 \mathrm{~m}$ x $4 \mathrm{~m}$ dengan jarak antar plot $1 \mathrm{~m}$.

\section{Persiapan Benih Padi}

Langkah awal penyemaian dilakukan dengan menyeleksi benih padi dengan cara merendamnya pada campuran air dan garam. Benih yang tenggelam merupakan benih yang bernas dan siap untuk digunakan. Selanjutnya benih dibersihkan/dicuci bersih untuk menghilangkan kandungan garamnya dan direndam selama 2 x 24 jam. Setelah itu, benih ditiriskan selama 1 x 24 jam. Persemaian menggunakan baki dengan campuran tanah yang digunakan adalah tanah pasir dan pupuk kotoran hewan dengan perbandingan 1:1. Fungsi digunakannya tanah bertekstur pasir agar pada saat pindah tanam, maka bibit padi dapat dipindahkan dengan mudah dengan tidak merusak bagian akarnya. Baki diberi alas daun pisang untuk menjaga kelembaban dari tanah yang digunakan untuk media tanam/persemaian. Benih pada persemaian secara rutin disiram/dibasahi 2 kali sehari (pagi dan sore). Setelah berumur 15-18 hari, maka bibit padi siap pindah tanam.

\section{Penanaman dan Pemeliharaan Tanaman}

Penanaman padi menggunakan jarak tanam $30 \mathrm{~cm}$ x $15 \mathrm{~cm}$. Setiap petak percobaan berisi 266 tanaman. Tiap lubang tanam berisi 1 bibit padi. Penanaman bibit padi pada kedalaman lubang tanam $\pm 3 \mathrm{~cm}$ atau perakaran dangkal. Selanjutnya pada 
tahap pengaturan air, pemberian air maksimal $2 \mathrm{~cm}$ dan tanah tidak diairi secara terus-menerus sampai terendam dan penuh, namun hanya dalam kondisi macak-macak hingga tanaman berumur 25-30 hari, maka bisa digenangi kembali. Tindakan tersebut untuk mengendalikan serangan keong mas pada masa awal penanaman. Pemeliharaan tanaman yang dilakukan meliputi manajemen pengairan dan penyiangan gulma yang dilakukan 1 minggu sekali. Penyiangan gulma dilakukan agar gulma yang tumbuh di sela-sela tanaman tidak mengganggu pertumbuhan tanaman padi. Pembuatan inlet dan outlet pada setiap petak perlakuan digunakan untuk sirkulasi air yang dibutuhkan dan meminimalisasi tercampurnya aliran air dari tiap plot perlakuan. Oleh karena itu, setiap petak perlakuan harus dipisahkan dengan guludan.

\section{Pengamatan Predator Laba-Laba}

Pengamatan dilakukan tiap minggu dari fase vegetatif sampai generatif. Waktu pengamatan (Pukul 05.30-10.30 WIB). Pengamatan dilakukan sejak tanaman padi berumur $5 \mathrm{mst}, 7 \mathrm{mst}, 9 \mathrm{mst}, 10$ mst, 12 mst, 14 mst, dan 16 mst. Adapun pengambilan pengamatan sampel dilakukan menggunakan 2 metode yaitu pengamatan secara langsung dan pengamatan sensus jaring laba-laba. Metode pengamatan langsung dilakukan dengan menetapkan titik pengamatan pada setiap petak sawah di tentukan 5 titik pengamatan, di setiap titik pengamatan di ambil 4 rumpun padi untuk diamati secara langsung. Bagian tanaman padi yang diamati mulai dari pangkal rumpun sampai tajuk tanaman. Laba-laba yang ada di titik pengamatan dimasukan ke dalam plastik dan di simpan di dalam botol film yang telah diisikan alkohol $70 \%$ untuk dilakukan perhitungan dan identifikasi. Metode ini bertujuan untuk mengetahui spesies laba-laba yang berada di bagian tanaman terutama bagian tajuk tanaman padi. Sementara itu, pengamatan sensus jaring laba-laba dilakukan dengan mengamati dan menghitung jumlah jaring laba-laba yang ada dipertanaman padi secara langsung. Pengamatan dilakukan pada setiap rumpun padi dengan jarak $1 \mathrm{~m}$, selanjutnya dihitung jumlah jaring laba-laba yang ada pada setiap tanaman. Perhitungan mulai dari pangkal rumpun tanaman sampai tajuk tanaman. Metode sensus jaring laba-laba ini dilakukan bertujuan untuk mengetahui jumlah jaring laba-laba yang ada di pertanaman padi.

\section{Identifikasi laba-laba}

Identifikasi laba-laba dilakukan di Laboratorium Hama Tumbuhan, Jurusan Hama dan Penyakit Tumbuhan, Fakultas Pertanian, Universitas Padjadjaran. Identifikasi laba-laba dilakukan dengan menggunakan kunci identifikasi yang tersedia seperti Barrion \& Litsinger (1995) dan Shepard et al. (1991).

\section{Analisis Data}

Keanekaragaman jenis ditentukan dengan rumus indeks keragaman jenis menurut Shannon Wienner (Brower \& Zar, 1977):

$\mathrm{H}^{\prime}=-\Sigma\{(\mathrm{ni} / \mathrm{N}) \operatorname{Ln}(\mathrm{ni} / \mathrm{N})\}$

dimana:

$\mathrm{H}^{\prime}=$ Indeks keanekaragaman jenis

$\mathrm{ni}=$ Jumlah individu tiap jenis

$\mathrm{N}=$ Jumlah total semua individu

Ln = Logaritma natural.

Kekayaan jenis ditentukan dengan rumus menurut Margalef (Ludwig \& Reynolds, 1988):

$\mathrm{R}=(\mathrm{s}-1) / \mathrm{Ln} \mathrm{N}$

dimana:

$\mathrm{R}=$ Indeks kekayaan jenis.

$\mathrm{s}=$ Jumlah jenis serangga.

$\mathrm{N}=$ Jumlah total individu serangga.

Ln = Logaritma natural.

Kemerataan jenis ditentukan dengan rumus menurut Piellou (1984):

\section{$\mathrm{E}=\mathrm{H}^{\prime} / \mathrm{Ln} \mathrm{s}$}

dimana:

$\mathrm{e}^{\prime}=$ Indeks kemerataan jenis.

$\mathrm{s}=$ Jumlah jenis.

$\mathrm{H}^{\prime}=$ Indeks keanekaragaman jenis.

$\mathrm{Ln}=$ Logaritma natural.

Indeks dominansi ditentukan dengan indeks dominansi Simpson (Ludwig \& Reynolds, 1988) dengan menggunakan rumus:

\section{$s$}

$\mathrm{C}=\Sigma(\mathrm{ni} / \mathrm{N})$

$\mathrm{i}=1$

dimana:

$\mathrm{D}=$ Indeks Diminansi

$\mathrm{s}=$ Jumlah spesies

$\mathrm{i}=$ Spesies ke

Kesamaan komunitas laba-laba, menggunakan Indeks Sorensen (Krebs, 1999; Ludwig \& Reynolds, 1988; Magurran, 1988):

$C s=2 j /(a+b)$

dimana :

$\mathrm{Cs}=$ koefisien kesamaan sorensen

$\mathrm{j}=$ jumlah spesies yang ada pada kedua sample

$\mathrm{a}=$ total jumlah spesies pada sample a

$\mathrm{b}=$ total jumlah spesies pada sample $\mathrm{b}$ 
Data komposisi spesies dan jumlah individu laba-laba digunakan untuk menganalisis kelimpahan dan keanekaragaman spesies. Ukuran keanekaragaman yang digunakan adalah Indeks Keanekaragaman Shannon-Wiever (H'), Indeks Dominansi (C) Berger-parker, Indeks Kemerataan (e') dan Indeks Kesamaan Sorensen (Cs). Hasil pengamatan dianalisis secara statistik dengan menggunakan program R Statistic 3.2.2. Pengujian perbedaan antara perlakuan menggunakan Analisis Varians (ANOVA) pada taraf nyata 5\%. Jika nilai $\mathrm{F}$ hitung lebih besar dari $\mathrm{F}$ tabel, maka analisis dilanjutkan untuk menguji perbedaan nilai rata-rata dengan Uji Tukey pada taraf 5\%.

\section{HASIL DAN PEMBAHASAN}

Kelimpahan Predator Laba-Laba pada Ekosisitem Sawah Padi Hitam Berpupuk Organik

Laba-laba adalah salah satu arthropoda pada ekosistem sawah yang populasinya dapat dipengaruhi oleh aktivitas bercocok tanam baik secara langsung maupun tidak langsung. Adapun pengaruh aktivitas bercocok tanam dapat bersifat negatif maupun positif terhadap komunitas labalaba. Aktivitas yang dapat memberikan pengaruh negatif antara lain dengan penggunaan bahan-bahan kimia baik pupuk ataupun pestisida sintetik (Settle, 1996). Sementara pada lahan yang menggunakan sistem pertanian organik peranan musuh alami sangat dominan untuk menekan populasi hama, misalnya dari kelas Arachnida (laba-laba) yang dapat bersifat spesifik maupun generalis. Kelimpahan labalaba pada berbagai perlakuan jenis pupuk dan ekosistem sawah padi hitam pada penelitian ini disajikan pada Tabel 1.

Data pada Tabel 1 menunjukkan bahwa kelimpahan individu laba-laba pada perlakuan pupuk ampas bungkil mimba berbeda nyata bila dibandingkan dengan perlakuan kontrol, pupuk kohe sapi dan NPK, namun tidak berbeda nyata dengan perlakuan pupuk gulma siam pada pengamatan 5-17 mst kecuali pengamatan 9 mst dimana semua perlakuan tidak berbeda nyata. Adanya perbedaan jenis pupuk yang digunakan secara tidak langsung berpengaruh terhadap populasi laba-laba pada ekosistem sawah padi hitam. Jayakumar \& Sankari (2010) menegaskan bahwa cara budidaya seperti pengolahan tanah, pemupukan dan pengelolaan organisme pengganggu tumbuhan (OPT) memengaruhi performa tanaman padi dan habitat sehingga secara tidak langsung berpengaruh terhadap kelimpahan laba-laba pada persawahan.

Tabel 1. Kelimpahan laba-laba pada berbagai perlakuan jenis pupuk di ekosistem sawah padi hitam

\begin{tabular}{lcccccccc}
\hline & \multicolumn{7}{c}{ Jumlah individu laba-laba pada pengamatan ke-..(mst) } \\
\cline { 2 - 8 } Perlakuan & 5 & 7 & 9 & 11 & 13 & 15 & 17 \\
\hline Kontrol & $35 \mathrm{a}$ & $26 \mathrm{~b}$ & $25 \mathrm{a}$ & $30 \mathrm{~b}$ & $35 \mathrm{~b}$ & $20 \mathrm{a}$ & $16 \mathrm{a}$ \\
Pupuk Ampas Bungkil Mimba & $43 \mathrm{~b}$ & $37 \mathrm{c}$ & $26 \mathrm{a}$ & $27 \mathrm{~b}$ & $34 \mathrm{~b}$ & $32 \mathrm{~b}$ & $21 \mathrm{~b}$ \\
Kompos Gulma Siam & $37 \mathrm{ab}$ & $35 \mathrm{c}$ & $24 \mathrm{a}$ & $33 \mathrm{~b}$ & $33 \mathrm{~b}$ & $29 \mathrm{~b}$ & $21 \mathrm{~b}$ \\
Pupuk Kohe Sapi & $32 \mathrm{a}$ & $27 \mathrm{~b}$ & $26 \mathrm{a}$ & $23 \mathrm{a}$ & $23 \mathrm{a}$ & $24 \mathrm{a}$ & $14 \mathrm{a}$ \\
NPK & $33 \mathrm{a}$ & $18 \mathrm{a}$ & $22 \mathrm{a}$ & $23 \mathrm{a}$ & $32 \mathrm{~b}$ & $20 \mathrm{a}$ & $18 \mathrm{ab}$ \\
\hline
\end{tabular}

Keterangan: Nilai yang diikuti oleh huruf yang sama dalam kolom menunjukkan tidak berbeda nyata pada taraf $5 \%$.

Tabel 2. Rerata individu laba-laba pada tiap familli pada perlakuan jenis pupuk

\begin{tabular}{|c|c|c|c|c|c|c|c|c|}
\hline \multirow[b]{2}{*}{ Perlakuan } & \multicolumn{8}{|c|}{ Famili* } \\
\hline & $\begin{array}{l}\text { Tetragnath } \\
\text { idae }\end{array}$ & Pholcidae & Lycosidae & $\begin{array}{c}\text { Oxyopida } \\
\text { e }\end{array}$ & $\begin{array}{l}\text { Linyphiid } \\
\text { ae }\end{array}$ & Araneidae & $\begin{array}{c}\text { Clubionid } \\
\text { ae }\end{array}$ & Theridiid $\varepsilon$ \\
\hline Kontrol & $17,57 \mathrm{a}$ & $3,00 \mathrm{a}$ & $0,14 \mathrm{a}$ & $0,43 a$ & $1,14 \mathrm{a}$ & $0,86 a$ & $0,00 \mathrm{a}$ & $0,00 \mathrm{a}$ \\
\hline $\begin{array}{l}\text { Pupuk Ampas Bungkil } \\
\text { Mimba }\end{array}$ & $21,24 b$ & $6,00 \mathrm{~b}$ & $0,86 a$ & $0,14 \mathrm{a}$ & $3,14 \mathrm{~b}$ & $0,29 a$ & $0,14 \mathrm{a}$ & $0,29 \mathrm{a}$ \\
\hline Pupuk Gulma siam & $20,71 b$ & $4,00 \mathrm{ab}$ & $1,00 \mathrm{a}$ & $0,29 a$ & $3,57 b$ & $0,71 \mathrm{a}$ & $0,00 \mathrm{a}$ & $0,00 \mathrm{a}$ \\
\hline Pupuk Kohe Sapi & $15,29 a$ & $4,29 \mathrm{ab}$ & $0,29 \mathrm{a}$ & $0,43 a$ & $2,43 \mathrm{ab}$ & $1,14 \mathrm{a}$ & $0,00 \mathrm{a}$ & $0,29 a$ \\
\hline NPK & $17,14 a$ & $2,29 a$ & $0,14 \mathrm{a}$ & $2,43 a$ & $0,00 \mathrm{a}$ & $1,00 \mathrm{a}$ & $0,00 \mathrm{a}$ & $0,14 \mathrm{a}$ \\
\hline
\end{tabular}

Keterangan: Rerata yang diikuti oleh huruf yang sama dalam kolom menunjukkan tidak berbeda nyata. 
Menurut Jayakumar \& Sankari (2010) dan Hendrival dkk. (2011), kelimpahan spesies laba-laba berbeda berdasarkan cara budidaya. Adapun kelimpahan laba-laba lebih tinggi pada cara budidaya dengan penggelolaan tanaman terpadu dan cara budidaya SRI (System of rice intensification). Hal ini dikarenakan sistem budidaya tanaman secara organik memberikan iklim mikro yang menguntungkan bagi kehidupan laba-laba yaitu memiliki ruang yang cukup antara tanaman dan baris tanaman serta keragaman vegetasi atau mangsa sehingga populasi Arthropoda predator menjadi tinggi. Selain itu, Herlinda dkk. (2008) juga melaporkan bahwa Tetragnathidae, Linyphiidae, Lycosidae, Pholcidae, Araneidae, Oxyopidae, Clubionidae, dan Theriididae adalah predator yang sering diketemukan pada persawahan dengan cara budidaya organik.

Famili Tetragnathidae, Pholcidae dan Linyphiidae merupakan kelompok laba-laba pembuat jaring (web spider) sedangkan famili Lycosidae, Oxyopidae, Clubionidae adalah laba-laba pemburu (hunting spider) (Tabel 2). Herlinda dkk. (2014) menyatakan bahwa laba-laba famili Tetragnathidae, Pholcidae dan Linyphiidae, merupakan laba-laba yang menangkap mangsanya dengan membuat jaring pada tajuk tanaman padi

Tabel 3. Nilai H', D, R, dan E, predator laba-laba pada beberapa perlakuan pupuk di ekosistem sawah padi hitam

\begin{tabular}{lccccc}
\hline \multirow{2}{*}{\multicolumn{1}{c}{ Parameter }} & \multicolumn{7}{c}{ Perlakuan } \\
\cline { 2 - 6 } & $\mathrm{A}$ & $\mathrm{B}$ & $\mathrm{C}$ & $\mathrm{D}$ & $\mathrm{E}$ \\
\hline Indeks Keanekaragaman (H') & 0,771 & 1,881 & 1,010 & 1,145 & 0,750 \\
Indeks Dominansi (D) & 0,368 & 0,532 & 0,496 & 0,551 & $-1,000$ \\
Indeks Kekayaan (R) & 0,769 & 1,289 & 0,940 & 1,159 & 0,798 \\
Indeks Kemerataan (E) & 0,479 & 0,905 & 0,564 & 0,588 & 0,466 \\
\hline
\end{tabular}

Keterangan: $\mathrm{A}=$ Kontrol, $\mathrm{B}=$ Pupuk ampas bungkil mimba, $\mathrm{C}=$ Pupuk gulma siam, $\mathrm{D}=$ Pupuk Kohe Sapi, $\mathrm{E}=\mathrm{NPK}$.

Lebih lanjut, nilai indeks dominansi menggambarkan pola dominansi jenis dalam komunitas. Nilai indeks yang tertinggi adalah 0,5 yang menunjukkan bahwa ekosistem tersebut didominasi oleh satu jenis atau terpusat pada satu jenis famili. Pada Tabel 3 menunjukkan bahwa pada perlakuan pupuk kotoran sapi terdapat famili yang mendominasi pada ekosistem tersebut. Nilai indeks dominansi dari kelima perlakuan tersebut relatif lebih rendah dari hasil yang dilaporkan oleh Pradhana dkk. (2014) yaitu sebesar 0,70 untuk sawah pertanaman padi organik. Merujuk pada Tabel 3, bahwa famili laba-laba yang mendominasi adalah Tetragnathidae sebagai laba-laba pembuat jaring. Sebastian et al. (2005) menegaskan bahwa dominasi oleh Tetragnathidae diduga bahwa lahan yang memiliki mobilitas tinggi dalam mencari mangsa dan mampu berpindah-pindah dari permukaan tanah menuju tajuk atau sebaliknya.

\section{Keanekaragaman Predator Laba-Laba pada Ekosisitem Sawah Padi Hitam Berpupuk Organik}

Indeks keragaman laba-laba pada perlakuan pupuk gulma siam, ampas bungkil mimba dan kotoran sapi lebih tinggi dibandingkan dengan perlakuan NPK dan kontrol (Tabel 3). Hal ini karena terdapat perbedaan sistem atau cara budidaya tanaman yang berpengaruh pada nilai keragaman. Widiarta dkk. (2006) menegaskan bahwa sistem budidaya pada ekosistem padi sawah yang dikaitkan dengan penggunaan jenis pupuk dapat mempengaruhi keanekaragaman musuh alami.

Nilai keanekaragaman pada perlakuan pupuk ampas bungkil mimba, gulma siam dan kohe sapi termasuk dalam tingkat keragaman sedang, sedangkan pada perlakuan pupuk NPK dan kontrol tergolong rendah (Tabel 2). Nelly dkk. (2015) menyatakan bahwa tingginya nilai keanekaragaman arthropoda ditentukan oleh distribusi jumlah individu pada tiap ekosistem. Oleh karena itu, perlu diupayakan pengelolaan budidaya padi hitam yang dapat meningkatkan stabilitas ekosistem sawah. yang organik, basah, kelimpahan mangsa dan vegetasi yang baik akan memberikan kondisi habitat yang cocok bagi perkembangan generasi laba-laba berikutnya.

Pada Tabel 3, nilai kekayaan jenis pada perlakuan pupuk ampas bungkil mimba dan gulma siam cenderung lebih tinggi dibandingkan dengan perlakuan NPK walaupun bila dilihat pada semua perlakuan termasuk kedalam kategori rendah. Selanjutnya, nilai indeks kemerataan pada perlakuan pupuk ampas bungkil mimba, gulma siam dan pupuk kotoran hewan lebih tinggi dibandingkan dengan perlakuan NPK dan kontrol. Hal ini menunjukkan bahwa kemerataan atau distribusi jenis serangga pada perlakuan pupuk ampas bungkil mimba dan gulma siam digolongkan sebagai kemerataan tinggi 
bila dibandingkan dengan perlakuan NPK. Sanjaya \& Dibiyantoro (2012) menyatakan bahwa semakin tinggi nilai indeks kemerataan, maka semakin sama peluang hidup dari setiap jenis serangga dalam sebuah komunitas.

Hasil analisis kesamaan komunitas laba-laba pada semua perlakuan menunjukan nilai kesamaan yang cukup tinggi (Tabel 4). Perlakuan pupuk ampas bungkil mimba mempunyai nilai kesamaan komunitas laba-laba tertinggi dengan perlakuan pupuk gulma siam, yaitu 91\%. Untuk hasil kesamaan komunitas laba-laba terendah yaitu perlakuan NPK dengan perlakuan pupuk ampas mimba sebesar 63\% dan perlakuan pupuk kohe sapi dengan perlakuan ampas bungkil mimba sebesar $80 \%$.

Tabel 4. Matriks kesamaan komunitas laba-laba (Indeks Serenson) pada beberapa perlakuan pupuk di ekosistem sawah padi hitam

\begin{tabular}{cccccc}
\hline Perlakuan & A & B & C & D & E \\
\hline A & - & & & & \\
B & 0,76 & - & & & \\
C & 0,86 & 0,91 & - & & \\
D & 0,74 & 0,80 & 0,71 & - & \\
E & 0,83 & 0,63 & 0,73 & 0,79 & - \\
\hline
\end{tabular}

Keterangan: $\mathrm{A}=$ Kontrol, $\mathrm{B}=$ Pupuk ampas bungkil mimba, $\mathrm{C}=$ Pupuk gulma siam, $\mathrm{D}=$ Pupuk kohe sapi, $\mathrm{E}=$ NPK.

Analisis kesamaan komunitas laba-laba menunjukkan bahwa komposisi spesies laba-laba antara perlakuan pupuk ampas mimba dan gulma siam lebih banyak kesamaannya dibandingkan dengan perlakuan lainnya. Indeks kesamaan komunitas pada kedua perlakuan tersebut digolongkan kategori tinggi karena nilainya mendekati 100\%. Menurut Krebs (1999), komunitas berbeda jika indeks kesamaan komunitas yang dibandingkan lebih kecil dari 50\%. Oleh karena itu, dapat dilihat bahwa perlakuan pupuk ampas bungkil mimba dan gulma siam cenderung meningkatkan kelimpahan dan keanekaragaman dari predator labalaba pada ekosistem padi hitam.

\section{SIMPULAN}

1. Kelimpahan laba-laba lebih tinggi pada perlakuan ampas bungkil mimba $(A$. indica) dan kompos gulma siam (C. odorata) di ekosistem sawah padi hitam.

2. Keanekaragaman laba-laba lebih tinggi pada perlakuan pupuk ampas bungkil mimba ( $A$. indica) dan kompos gulma siam ( $C$. odorata) di ekosistem sawah padi hitam.

\section{UCAPAN TERIMAKASIH}

Penulis mengucapkan terima kasih kepada DRPMI Universitas Padjadjaran yang telah membeikan dana hibah Riset Fundamental (RFU) tahun 2018.

\section{DAFTAR PUSTAKA}

Altieri, MA, and CI Nicholls. 1999. Biodiversity, Ecosystem Function and Insect Pest Management in Agriculture System. CRC Press LLC. USA. 279-280p.

Amengor, MG, and FM Tetteh. 2008. Effect of Pesticide Application Rate on Yield of Vegetables and Soil Microbial Communities. West African Journal of Applied Ecology. 12(1): 1-7.

Anggraini, F, A Suryanto, dan N Aini. 2014. Sistem tanam dan umur bibit pada tanaman padi sawah (Oryza sativa L) varietas Inpari 13. Jurnal Produksi Tanaman. 1(2): 52-60.

Anjali, and S Prakash. 2012. Diversity of spiders (Aranea) from semi-arid habitat of Agra (India). Indian Journal of Arachnology. 1: 6672.

Barrion, AT, and JA Litsinger. 1995. Riceland Spiders of South and Southeast Asia. CAB International. Wallingford. UK.

Brower, JE, and JH Zar. 1977. Field and Laboratory Methods for General Ecology. Wm. C. Brown Company Publishers. Boston.

Dewi, VK, NS Putra, B Purwanto, S Sari, S Hartati, dan L Rizkie. 2019. Pengaruh aplikasi kompos gulma Siam Chromolaena odorata terhadap produksi senyawa metabolit sekunder sebagai ketahanan tanaman pada tanaman cabai. Soilrens. 17(1): 16-23.

Hadi, M, dan Aminah. 2012. Keragaman serangga dan perannya di ekosistem sawah. Jurnal Sains dan Matematika. 20(3): 54-57.

Hendrival, P Hidyat, dan A Nurmansyah. 2011. Keanekaragaman dan kelimpahan musuh alami Bemisia tabaci (Gennadius) (Hemiptera: Aleyrodidae) pada pertanaman cabai merah di Kecamatan Pakem, Kabupaten Sleman, Daerah Istimewa Yogyakarta. Jurnal Entomologi Indonesia. 8(2): 96-109.

Herlinda, S, Waluyo, SP Estuningsih, dan C Irsan. 2008. Perbandingan keanekara gaman spesies dan kelimpahan arthropoda predator penghuni tanah di sawah lebak yang 
diaplikasi dan tanpa aplikasi insektisida. J. Entomol. 5(2): 96-107.

Herlinda, S, HCN Manalu, RF Aldina, Suwandi, A Wijaya, Khodijah, dan D Meidalima. 2014. Kelimpahan dan keanekaragaman spesies laba-laba predator hama padi ratun di sawah pasang surut. J. HPT Tropika. 14(1): 1-7.

Jayakumar, S, and A Sankari. 2010. Spider population and their predatoryefficiency in different rice establishment techniques in Aduthurai, Tamil Nadu. Journal of Biopesticides. 3(1): 20-27.

Krebs, CJ. 1989. Ecology methodology. Herper Collins Publisher. New York.

Kristamtini, dan H Purwaningsih. 2009. Potensi pengembangan beras merah sebagai plasma nutfah Yogyakarta. J. Litbang Pertanian. 28(3): 88-95.

Ludwig, JA, and JF Reynolds. 1988. Statistical Ecology. A Primer on Method and Computing. John Wiley and Sons, Inc. New York.

Magurran, AE. 1988. Ecological Diversity and Its Measurement. Princeton University Press. New Jersey.

Makarim, AK, dan I Las. 2005. Terobosan peningkatan produktivitas padi sawah irigasi melalui pengembangan model pengelolaan tanaman sumberdaya terpadu (PTT). Inovasi Teknologi Padi menuju Swasembada Beras Berkelanjutan. Buku satu. Balitbangtan, Badan Litbang Pertanian. Jakarta. Hlm. 116-123.

Marsono, dan P Sigit 2001. Pupuk Kandang dan Aplikasi Pupuk Akar. Penebar Swadaya. Jakarta.

Memah, VV, M Tulung, J Warouw, and RRTD Maramis. 2014. Diversity of spider species in some agricultural crops in North Sulawesi, Indonesia. International Journal of Scientific \& Engineering Research. 5: 70-75.

Nelly, N, Trizelia, dan Q Syuhadah. 2012. Tanggap fungsional Menochilus sexmaculatus Fabricius (Coleoptera: Coccinellidae) terhadap Aphis gossypii (Glover) (Homoptera: Aphididae) pada umur tanaman cabai berbeda. J. Entomol. Indon. 9(1): 23-31.

Piellou, EC. 1984. The interpretation of Ecological Data. A Primer on Classification and Ordination. A Wiley \& Sons. New York.

Pradhana, RAI, G Mudjiono, dan S Karindah. 2014. Keanekaragaman serangga dan laba-laba pada pertanaman padi organik dan konvensional. Jurnal HPT. 2(2): 58-66.
Radix, S, dan TN Aeny. 2011. Eksplorasi potensi gulma siam (Chromolaena odorata) sebagai biofungisida pengendali Phytophthora palmivora yang diisolasi dari buah kakao. J. HPT Tropika. 11(2): 201-209.

Rivaie, AA. 2009. Mengelola Kesuburan Tanah secara Tepat - Suatu Kunci Memaksimalkan Produktivitas Lada. Info Perkebunan 22. Pusat Penelitian dan Pengembangan Perkebunan.

Sanjaya, Y, dan ALH Dibiyantoro. Keragaman serangga pada tanaman cabai (Capsicum annuum) yang diberi pestisida sintetis versus biopestisida racun laba-laba (Nephila sp.). Jurnal HPT Tropika. 12(2): 192-199.

Schmutterer, H. 1990. Properties and potential of natural pesticides from neem tree, Azadirachta indica. Ann. Rev. Entomol. 35: 271-291.

Sebastian, PA, MJ Mathew, S Pathummal-Beevi, J Joseph, and CR Biju. 2005. The spider fauna of the irrigated rice ecosystem in central Kerala, India across different elevational ranges. The Journal of Arachnology. 33: 247255.

Settle, WH, H Ariawan, ET Astuti, W Cahyana, AL Hakim, D Hindayana, AS Lestari, and Pajarningsih. 1996. Managing tropical rice pest through conservation of generalist natural enemies and alternative prey. Ecology. 77: 1975-1988.

Shepard, BM, AT Barrion, and JA Litsinger. 1991. Friends of The Rice Farmer: Helpful Insects, Spiders, and Pathogens. International Rice Research Institute. Los Banos. 111-118p.

Siswanto, dan Wiratmo. 2001. Biodiversitas serangga pada pertanaman panili (Vanilla planifolia) dengan tanaman penutup tanah Arachis pintoi K. Prosiding Seminar Nasional Perhimpunan Entomologi Indonesia 6 Nopember 2001. Hlm. 209-215.

Sosromarsono, S, dan K Untung. 2000. Keanekaragaman hayati artropoda predator dan parasit di Indonesia dan pemanfaatannya. Simposium Keanekaragaman Hayati Arthropoda pada Sistem Produksi Pertanian. Perhimpunan Entomologi Indonesia (PEI). Cipayung, Bogor. 16-18) Oktober 2000. Hlm. 33-45.

Suntoro, 2001. Pengaruh residu penggunaan bahan organik, dolomit dan $\mathrm{KCl}$ pada tanaman kacang tanah (Arachis hypogeae L.) pada oxic dystrudept di Jumapolo, Karanganyar. Habitat. 12(3): 170-177. 
Ulpa, M. 2008. Studi Habitat dan Pengujian Ekstrak Gulma Siam (Chromolaena odorata) dalam Menghambat Pertumbuhan Bakteri Penyebab Penyakit Layu Pisang (Ralstonia sp.) secara In Vitro. [Skripsi]. Universitas Lampung. Bandar Lampung.

Wahdah, R, dan BF Langai. 2009. Observasi varietas padi lokal di lahan pasang surut Kalimantan Selatan. Agroscientiae. 16(3): 177-184.

Widiarta, IN, D Kusdiaman, dan Suprihanto. 2006. Keragaman arthropoda pada padi sawah dengan pengelolaan tanaman terpadu. J. HPT Tropika. 6(2): 61-69.
Widiarta, IN, T Suryana, dan D Kusdiaman. 2001. Jenis anggota komunitas pada berbagai habitat lahan sawah bera dan usaha konservasi musuh alami pada padi tanaman serempak. Prosiding Simposium Keanekaragaman Hayati Arthropoda pada Sistem Produksi Pertanian. Perhimpunan Entomologi Indonesia. Cipayung, Bogor. Hlm. 185-192.

Wilson, MA, S Meaux, and AV Hoof. 2008. Diverse aberrancies target yeast mRNAs to cytoplasmic mRNA surveillance pathways. Biochim Biophys Acta. 1779(9): 550-557. 